\title{
KONTAMINASI BAKTERI PADA TELEPON GENGGAM PESERTA PROGRAM PENDIDIKAN DOKTER SPESIALIS-1 ILMU KESEHATAN ANAK, FAKULTAS KEDOKTERAN, UNIVERSITAS AIRLANGGA-RSUD Dr. SOETOMO
}

\author{
Marsananda Yunitasari ${ }^{\star 凶}$, Marijam Purwanta** Mahrus Abdur Rahman ${ }^{\star \star *}$
}

\begin{abstract}
Abstrak
Masyarakat termasuk kalangan tenaga medis menggunakan telepon genggam dalam kehidupan sehari-hari. Penggunaan telepon genggam dalam dunia medis memiliki banyak manfaat untuk melayani pasien. Namun, telepon genggam tenaga medis dapat berisiko menjadi media penyebaran infeksi atau disebut juga sebagai sumber eksogen infeksi nosokomial kepada pasien yang memiliki faktor risiko. Sebagai tenaga medis, maka peserta Program Pendidikan Dokter Spesialis-1 IImu Kesehatan Anak, menangani pasien neonatus, bayi, dan anak di IRNA, NICU, dan PICU selama masa studinya. Pasien tersebut memiliki faktor risiko infeksi nosokomial karena sistem imun yang belum matur dan penggunaan alat medis invasif. Penelitian ini bertujuan untuk mengetahui adanya kontaminasi bakteri pada telepon genggam peserta PPDS-1 IImu Kesehatan Anak, Fakultas Kedokteran, Universitas Airlangga-RSUD Dr. Soetomo dan jenis bakteri pada telepon genggam. Penelitan ini merupakan penelitian deskriptif dengan studi cross sectional menggunakan kultur swab telepon genggam pada bulan Februari 2021. Hasil menunjukkan bahwa sebanyak 8 (32\%) telepon genggam steril dan $17(68 \%)$ telepon genggam terkontaminasi bakteri. Jenis bakteri kontaminan pada telepon genggam adalah bakteri Staphylococcus koagulase negatif/coagulase negative Staphylococci (CoNS) (90,5\%) dan bakteri Staphylococcus aureus koagulase positif $(9,5 \%)$. Kesimpulan pada penelitian ini yaitu bakteri pada telepon genggam didominasi oleh bakteri Staphylococcus koagulase negatif. Saran bagi penelitian selanjutnya yaitu melakukan penelitian dengan menggunakan besar sampel lebih banyak untuk mengetahui seberapa besar korelasi bakteri CoNS dan Staphylococcus aureus koagulase positif pada telepon genggam dengan angka kejadian penyakit infeksi.
\end{abstract}

Kata kunci: bakteri, telepon genggam PPDS

\section{BACTERIAL CONTAMINATION OF RESIDENTS' MOBILE PHONES IN DEPARTMENT OF CHILD HEALTH, FACULTY OF MEDICINE, UNIVERSITAS AIRLANGGA- Dr. SOETOMO GENERAL HOSPITAL}

\begin{abstract}
Most people including healthcare workers use mobile phones in their daily lives. Mobile phone usage in medical practice has many benefits for serving patients. Nevertheless, healthcare workers' mobile phones can be a risk as a vehicle for infection spreading or also referred to as an exogenous source of nosocomial infection for patients with risk factors. As healthcare workers, the residents of pediatric departments, treat neonates, infants, and children at wards, NICU, and PICU during their studies. These patients have risk factors of nosocomial infection because of immature immune systems and usage of medical invasive equipment. This study aimed was to determine bacterial contamination of residents' mobile phones in the Department of Child Health, Faculty of Medicine, Universitas Airlangga-Dr. Soetomo General Hospital and to identify bacterial isolates on these mobile phones. This was descriptive research with a cross-sectional study that used mobile phone swab culture in February 2021. The result showed that $8(32 \%)$ mobile phones were sterile and $17(68 \%)$ mobile phones were contaminated with bacteria. The bacteria as contaminants on mobile phones are coagulase-negative Staphylococci (CoNS) (90.5\%) and positive coagulase Staphylococcus aureus $(9.5 \%)$. The conclusion is that the bacteria on mobile phones are dominated by CoNS bacteria. Suggestion for further research is to conduct a study using a larger sample size to find out the correlation between CoNS and positive coagulase Staphylococcus aureus on mobile phones with the incidence of infectious disease.
\end{abstract}

Keywords: bacteria, residents' mobile phones

* Program Studi Kedokteran, Fakultas Kedokteran, Universitas Airlangga

** Departemen Mikrobiologi Kedokteran, Fakultas Kedokteran, Universitas Airlangga-RSUD Dr. Soetomo, Surabaya

*** Departemen IImu Kesehatan Anak, Fakultas Kedokteran, Universitas Airlangga-RSUD Dr. Soetomo, Surabaya

$\llbracket$ marsananda.yunitasari-2018@fk.unair.ac.id 


\section{Pendahuluan}

Penggunaan telepon genggam dalam dunia medis bermanfaat untuk melayani pasien, antara lain media konsultasi, melihat hasil laboratorium dan radiologi pasien, serta mencari referensi pengobatan. ${ }^{1-3} \mathrm{Di}$ sisi lain, telepon genggam tenaga medis dapat berisiko menjadi media penyebaran infeksi kepada pasien..$^{2-4}$

Ketika tenaga medis bekerja, maka bagian tubuhnya, seperti tangan, wajah, dan telinga, sering bersinggungan dengan mikroorganisme di lingkungan rumah sakit. Hal ini menjadi salah satu faktor risiko terjadinya kontaminasi telepon genggam tenaga medis oleh mikroorganisme dari bagian tubuh tersebut. ${ }^{1-3}$ Hasil penelitian yang dilakukan di Kuwait, Arab Saudi, dan Etiopia Utara, menunjukkan bahwa $63,3 \%$ hingga $94,2 \%$ telepon genggam tenaga medis terkontaminasi bakteri. ${ }^{3-5}$ Sebagian besar bakteri kontaminan telepon genggam merupakan bakteri penyebab infeksi nosokomial, yaitu Staphylococcus aureus, Staphylococcus koagulase negatif, Acinetobacter spp., Pseudomonas spp., Klebsiella spp., Streptococcus spp., dan Escherichia coli. ${ }^{3-5}$

Infeksi nosokomial atau Healthcare Associated Infections (HAls) adalah infeksi yang terjadi pada pasien selama proses perawatan di rumah sakit dan timbul minimal dalam waktu 48 jam setelah perawatan di rumah sakit. Kriteria lain infeksi nosokomial yaitu pasien tidak menunjukkan gejala infeksi saat masuk rumah sakit pertama kali. ${ }^{6}$ Berdasarkan data WHO, prevalensi infeksi nosokomial di Indonesia pada periode tahun 1995-2010 mencapai 7,1\%.6 Infeksi nosokomial dapat disebabkan oleh bakteri yang berasal dari sumber endogen dan sumber eksogen. Sumber endogen berasal dari bagian tubuh pasien sendiri, seperti kulit, hidung, dan saluran cerna. Tangan tenaga medis yang terkontaminasi, lingkungan rumah sakit, alat medis dan aksesoris lainnya (misalnya telepon genggam tenaga medis) di rumah sakit dapat menjadi sumber eksogen infeksi nosokomial. ${ }^{2-4}$

Beberapa keadaan pasien bisa menjadi faktor risiko infeksi nosokomial, misalnya pasien yang dirawat di ruang Intensive Care Unit (ICU) dengan menggunakan kateter vena dan endotracheal tube serta yang menjalani perawatan di rumah sakit lebih dari 7 hari.4,6 Pasien neonatus dan bayi juga berisiko untuk terkena infeksi nosokomial karena sistem imun yang belum matur dan barier kulit tidak cukup kuat untuk melawan mikroorganisme di lingkungan. 4,7 Prevalensi infeksi nosokomial pada neonatus, bayi, dan anak-anak mencapai $7,77 \%$ hingga $45,8 \% .8-10$

Salah satu kalangan tenaga medis yang menangani pasien dengan faktor risiko infeksi nosokomial adalah peserta Program Pendidikan Dokter Spesialis-1 IImu Kesehatan Anak (PPDS-1 IKA). Dokter peserta PPDS-1 IImu Kesehatan Anak mendapatkan kesempatan untuk belajar dan menangani pasien neonatus, bayi, dan anak (termasuk remaja) di Instalasi Rawat Inap (IRNA) anak, Neonatal Intensive Care Unit (NICU), dan Pediatric Intensive Care Unit (PICU) selama masa studinya. ${ }^{11}$

Berdasarkan paparan di atas, maka dilakukan penelitian untuk mengetahui adanya kontaminasi bakteri pada telepon genggam yang digunakan oleh peserta PPDS -1 IImu Kesehatan Anak Fakultas Kedokteran Universitas Airlangga-RSUD Dr. Soetomo dan mengidentifikasi jenis bakteri kontaminan pada telepon genggam tersebut.

\section{Bahan dan Metode}

\section{Rancangan Penelitian}

Penelitian ini adalah penelitian deskriptif dengan studi cross sectional menggunakan kultur swab telepon genggam peserta PPDS1 IImu Kesehatan Anak Fakultas Kedokteran Universitas Airlangga-RSUD Dr. Soetomo pada bulan Februari 2021. 
Penelitian ini telah mendapatkan izin dari Komite Etik Penelitian Kesehatan RSUD Dr. Soetomo dengan nomor kelaikan etik 0109/ KEPK/XII/2020.

\section{Populasi dan Sampel Penelitian}

Populasi penelitian adalah peserta PPDS-1 IImu Kesehatan Anak Fakultas Kedokteran Universitas Airlangga-RSUD Dr. Soetomo. Sampel penelitian adalah peserta PPDS-1 IImu Kesehatan Anak Fakultas Kedokteran Universitas Airlangga-RSUD Dr. Soetomo yang memenuhi kriteria inklusi, yaitu 1). Memiliki telepon genggam dengan jenis layar sentuh, 2). Sedang menjalani rotasi pendidikan klinis pada tahap junior (semester 2-semester 4), madya (semester 5-trimester I semester 8), dan senior (trimester || semester 8-semester 9), 3). Bersedia menjadi responden dengan menandatangani informed consent, dan 4). Hadir saat pengambilan spesimen swab telepon genggam.

\section{Besar Sampel Penelitian}

Besar sampel ditentukan menggunakan rumus besar sampel deskriptif kategorik dan rumus koreksi besar sampel untuk antisipasi drop out. Proporsi variabel yang diteliti $(\mathrm{P})$ berdasarkan prevalensi telepon genggam yang terkontaminasi bakteri pada penelitian di Hiwot Fana Specialized University Hospital, yaitu $94,2 \% .^{3}$

Rumus besar sampel deskriptif kategorik

$$
\begin{aligned}
& n=\frac{Z a^{2} \times P \times Q}{d^{2}} \\
& n=\frac{(1,96)^{2} \times 0,942 \times 0,058}{(0,1)^{2}} \\
& n=20,9(\text { dibulatkan menjadi 21) }
\end{aligned}
$$

Rumus koreksi besar sampel untuk antisipasi drop out

$$
\begin{aligned}
& n=\frac{n}{1-f} \\
& n=\frac{21}{(1-0,15)} \\
& n=24,7 \text { (dibulatkan meniadi 25) }
\end{aligned}
$$

Dengan demikian, besar sampel penelitian ini adalah 25 sampel peserta PPDS-1 IImu Kesehatan Fakultas Kedokteran Universitas Airlangga-RSUD Dr. Soetomo yang memiliki telepon genggam dengan jenis layar sentuh.

\section{Teknik Pengambilan Sampel Penelitian}

Teknik pengambilan sampel penelitian ini adalah purposive sampling, yaitu pengambilan sampel yang dilakukan dengan mengacu kriteria inklusi.

\section{Variabel Penelitian}

Variabel penelitian meliputi: 1). Adanya kontaminasi bakteri pada telepon genggam peserta PPDS-1 IImu Kesehatan Anak Fakultas Kedokteran Universitas AirlanggaRSUD Dr. Soetomo dan 2). Jenis bakteri pada hasil swab telepon genggam peserta PPDS-1 IImu Kesehatan Anak Fakultas Kedokteran Universitas Airlangga-RSUD Dr. Soetomo.

\section{Lokasi Penelitian}

Pengambilan sampel dan spesimen swab telepon genggam di RSUD Dr. Soetomo, sedangkan pengolahan spesimen swab telepon genggam di Departemen Mikrobiologi Kedokteran, Fakultas Kedokteran, Universitas Airlangga.

\section{Pemilihan dan Pengambilan Sampel}

Tahapan pemilihan dan pengambilan sampel meliputi: 1). Pengumpulan daftar anggota populasi peserta PPDS-1 IImu Kesehatan Anak, Fakultas Kedokteran, Universitas Airlangga-RSUD Dr. Soetomo, 2). Pengisian informed consent dilakukan pada anggota populasi yang sedang menjalani rotasi pendidikan rotasi klinis di tahap junior, madya, atau senior, 3). Responden yang telah mengisi kesediaan dalam informed consent wajib hadir pada bulan Februari 2021 untuk satu kali pengambilan spesimen swab telepon genggam. 
Pengambilan Spesimen Swab Telepon Genggam

Pengambilan 25 spesimen swab telepon genggam berasal dari telepon genggam yang dominan digunakan oleh 25 sampel. Pengambilan tersebut dilakukan pada tanggal 15-18 Februari 2021. Pengambilan spesimen swab tiap telepon genggam dilakukan dengan cara mengusap (swab) seluruh bagian layar telepon genggam yang menggunakan kapas lidi steril secara aseptik. Kapas lidi steril tersebut dimasukkan ke dalam medium transpor Amies dan dibawa ke laboratorium Departemen Mikrobiologi Kedokteran, Fakultas Kedokteran, Universitas Airlangga dalam waktu 24 jam setelah pengambilan spesimen. 2,4

\section{Inokulasi Spesimen}

Inokulasi tiap spesimen swab telepon genggam pada medium Blood Agar dan Mac Conkey secara aseptik, kemudian diinkubasi pada suhu $37^{\circ} \mathrm{C}$ selama 24 jam. Kontaminasi bakteri pada telepon genggam ditunjukkan dengan adanya pertumbuhan bakteri pada salah satu atau kedua medium, sedangkan tidak adanya kontaminasi bakteri ditunjukkan dengan tidak ada pertumbuhan bakteri pada kedua medium. 2,4

\section{Identifikasi Morfologi Koloni}

Koloni bakteri yang tumbuh pada medium Blood Agar dan medium Mac Conkey diidentifikasi secara makroskopik dan mikroskopik. Identifikasi makroskopik meliputi bentuk, konsistensi, dan warna koloni. Identifikasi mikroskopik dilakukan dengan pewarnaan Gram untuk melihat morfologi bakteri.2

\section{Identifikasi Bakteri}

Beberapa uji biokimia yang berbeda, antara lain uji katalase, koagulase, medium Mannitol Salt Agar, uji kepekaan Novobiocin, Triple Sugar Iron Agar, indol, Methyl Red, Voges Proskauer, urease, sitrat, dan motilitas, digunakan untuk mengidentifikasi spesies bakteri berdasarkan hasil pewarnaan Gram (Gambar 1).3,12

\section{Analisis Data}

Analisis data dilakukan secara deskriptif. Data yang telah dikelompokkan berdasarkan variabel disajikan dalam bentuk tabel persentase.

\section{Hasil}

\section{Karakteristik Sampel}

Mayoritas sampel peserta PPDS-1 IImu Kesehatan Anak, Fakultas Kedokteran, Universitas Airlangga-RSUD Dr. Soetomo adalah perempuan $(80 \%)$, dengan kelompok usia 27-31 tahun (44\%), tingkat madya (64\%), dan bekerja di Divisi Endokrinologi (16\%) (Tabel 1).

Kontaminasi Bakteri pada Telepon Genggam dan Jenis Bakteri Kontaminan

Dari 25 spesimen swab telepon genggam, sebanyak $68 \%$ atau 17 spesimen swab telepon genggam menunjukkan adanya kontaminasi bakteri. Namun, pada 4 spesimen swab telepon genggam ditemukan 2 jenis bakteri yang berbeda, sehingga jumlah total adalah 21 isolat bakteri. Dari keseluruhan isolat bakteri yang ditemukan, $100 \%$ bakteri Gram positif, yang didominasi oleh $90,5 \%$ bakteri Staphylococcus koagulase negatif (CoNS), yaitu terdiri dari bakteri Staphylococcus aureus koagulase negatif, Staphylococcus epidermidis, dan Staphylococcus saprophyticus. Bakteri Staphylococcus aureus koagulase positif menjadi bakteri kontaminan telepon genggam paling sedikit $(9,5 \%)$ (Tabel 2).

\section{Pembahasan}

\section{Kontaminasi Bakteri pada Telepon Genggam}

Hasil penelitian menunjukkan bahwa sebanyak 17 (68\%) telepon genggam peserta PPDS-1 IImu Kesehatan Anak Fakultas Kedokteran Universitas Airlangga-RSUD Dr. Soetomo terkontaminasi oleh bakteri. 


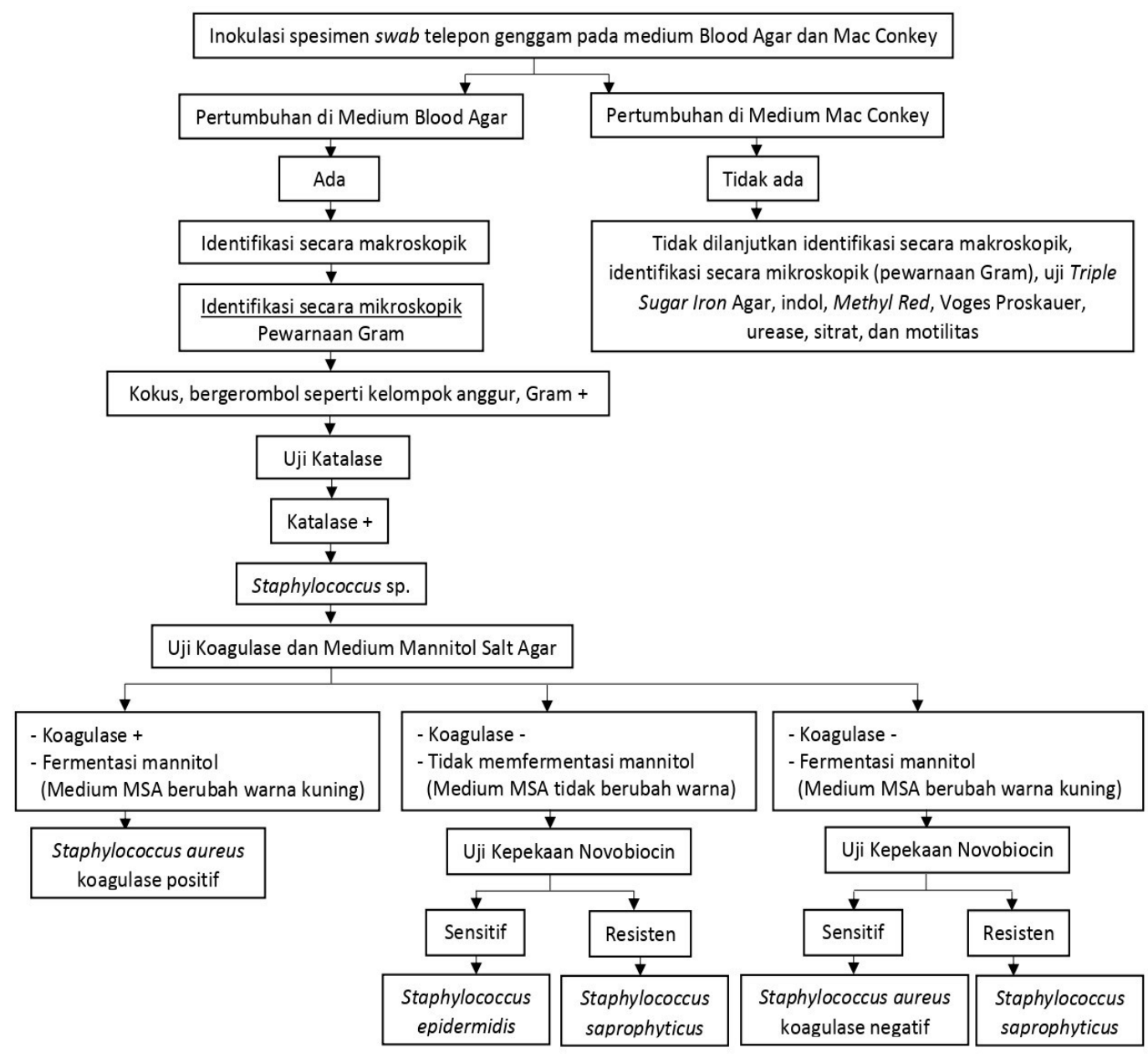

Gambar 1. Identifikasi spesies bakteri pada spesimen swab telepon genggam (Sumber: Olahan Peneliti yang merupakan adaptasi dari beberapa referensi $3,12-20)$

Keterangan: (+) positif, (-) negatif

Tabel 1. Karakteristik sampel peserta PPDS-1 IImu Kesehatan Anak, Fakultas Kedokteran, Universitas Airlangga-RSUD Dr. Soetomo $(n=25)$

\begin{tabular}{|c|c|c|}
\hline Karakteristik & Frekuensi & Persentase (\%) \\
\hline \multicolumn{3}{|l|}{ Jenis Kelamin } \\
\hline Laki-laki & 5 & 20 \\
\hline Perempuan & 20 & 80 \\
\hline \multicolumn{3}{|l|}{ Usia (tahun) } \\
\hline $27-31$ & 11 & 44 \\
\hline $32-36$ & 9 & 36 \\
\hline $37-41$ & 5 & 20 \\
\hline Tahapan Rotasi Pendidikan Klinis & $\overline{6}$ & 24 \\
\hline Junior & 16 & 64 \\
\hline Madya & 3 & 12 \\
\hline Senior & & \\
\hline
\end{tabular}


Lanjutan Tabel 1. Karakteristik sampel peserta PPDS-1 IImu Kesehatan Anak, Fakultas Kedokteran, Universitas Airlangga-RSUD Dr. Soetomo $(n=25)$

\begin{tabular}{lcc}
\hline \multicolumn{1}{c}{ Karakteristik } & Frekuensi & Persentase (\%) \\
\hline Rotasi Tempat Kerja & & \\
Divisi Nutrisi dan Penyakit Metabolik (NPM) & 2 & 8 \\
Divisi Nefrologi & 1 & 4 \\
Divisi Endokrinologi & 4 & 16 \\
Divisi Tumbuh Kembang & 2 & 8 \\
Divisi Tropik-Infeksi & 1 & 4 \\
Divisi Hematologi-Onkologi & 1 & 4 \\
Divisi Respirologi & 2 & 8 \\
Divisi Gastro-Hepatologi & 1 & 4 \\
Divisi Neonatologi & 2 & 8 \\
Divisi Kardiologi & 2 & 8 \\
Divisi Alergi-Imunologi & 2 & 8 \\
Divisi Neurologi & 2 & 8 \\
Poliklinik & 3 & 12 \\
\hline
\end{tabular}

Tabel 2. Jenis bakteri kontaminan pada telepon genggam peserta PPDS-1 IImu Kesehatan Anak, Fakultas Kedokteran, Universitas Airlangga-RSUD Dr. Soetomo

\begin{tabular}{lcc}
\hline \multicolumn{1}{c}{ Bakteri } & Frekuensi & Persentase $(\%)$ \\
\hline Staphylococcus aureus koagulase positif & 2 & 9,5 \\
Staphylococcus aureus koagulase negatif & 6 & 28,6 \\
Staphylococcus epidermidis & 6 & 28,6 \\
Staphylococcus saprophyticus & 7 & 33,3 \\
Jumlah & 21 & 100 \\
\hline
\end{tabular}

Persentase telepon genggam yang terkontaminasi bakteri pada penelitian ini lebih rendah daripada penelitian sebelumnya yang dilakukan pada telepon genggam dokter spesialis anak di University Hospital of SaintEtienne, Perancis, tahun 2015-2016 dan tenaga medis di NICU Mohamed VI University Hospital, Marrakesh, Maroko, tahun 2016, menunjukkan sekitar 94\% hingga 100\% telepon genggam yang terkontaminasi bakteri.21,22 Perbedaan persentase telepon genggam yang terkontaminasi bakteri terjadi karena peneltian ini dilakukan pada masa pandemi COVID-19, sehingga $32 \%$ dari 25 sampel melapisi telepon genggam dengan plastik dan sering mengganti lapisan plastiknya sebagai bentuk pencegahan penularan COVID-19.

Coronavirus Disease 2019 (COVID-19) adalah penyakit yang disebabkan virus
Severe Acute Respiratory Syndrome Coronavirus 2 (SARS-CoV-2). ${ }^{23}$ Penularan utama COVID-19 melalui droplet, baik secara langsung maupun tidak langsung. ${ }^{23,24} \mathrm{Di}$ saat pandemi ini, Centers of Disease Control and Prevention (CDC) merekomendasikan protokol kesehatan bagi tenaga medis untuk mencegah terjadinya penularan COVID-19 di fasilitas kesehatan, antara lain 1) hand hygiene, 2) pembersihan dan desinfeksi permukaan benda yang sering tersentuh termasuk telepon genggam, 3) pemakaian alat perlindungan diri seperti sarung tangan, masker medis, goggles, dan face shield, 4) respiratory hygiene. ${ }^{24}$ Hand hygiene dan desinfeksi benda yang sering tersentuh, termasuk telepon genggam juga berperan dalam mereduksi jumlah kontaminasi bakteri pada telepon genggam..$^{3,25}$ 
Jenis Bakteri Kontaminan pada Telepon Genggam

Keseluruhan bakteri yang menjadi kontaminan telepon genggam pada penelitian ini adalah bakteri Gram positif (100\%). Persentase bakteri Gram positif lebih besar daripada bakteri Gram negatif juga terlihat pada penelitian sebelumnya. Penelitian Haghbin et al. (2015) di PICU dan NICU Namazi Hospital, Iran, menunjukkan bahwa persentase kontaminan bakteri Gram positif pada telepon genggam tenaga medis, yaitu $93 \%$, lebih besar dibandingkan dengan kontaminan bakteri Gram negatif, yaitu 7\%.26 Penelitian lain yang dilakukan pada telepon genggam tenaga medis di Departemen IImu Kesehatan Anak di Rumah Sakit Kota Zagazig, Mesir, menunjukkan bahwa kontaminasi telepon genggam didominasi oleh bakteri Gram positif, sebanyak 95,7\%, sedangkan persentase bakteri Gram negatif adalah $4,3 \% .{ }^{27}$

Salah satu kemungkinan faktor risiko yang dapat menjelaskan bahwa bakteri Gram positif lebih dominan sebagai kontaminan telepon genggam adalah karena telepon genggam sering bersinggungan dengan kulit, terutama di bagian tangan. ${ }^{1}$ Sebagian besar bakteri flora normal di kulit adalah bakteri Gram positif, sedangkan bakteri Gram negatif tidak selalu ditemukan pada kulit yang normal.28,29 Spesies bakteri Gram positif yang menjadi kontaminan telepon genggam dalam penelitian ini dapat diketahui melalui langkahlangkah identifikasi pada Gambar 1, termasuk uji kepekaan Novobiocin. Bakteri pada penelitian ini dapat dibagi dua jenis berdasarkan uji koagulase, yaitu bakteri Staphylococcus aureus koagulase positif dan bakteri Staphylococcus koagulase negatif atau Coagulase Negative Staphylococci (CoNS).

Salah satu bakteri CoNS pada penelitian ini adalah bakteri Staphylococcus aureus koagulase negatif. Penelitian ini menemukan bakteri Staphylococcus aureus dengan ciri-ciri pada umumnya berdasarkan identifikasi makroskopik, pewarnaan Gram, uji katalase, adanya fermentasi mannitol, dan uji kepekaan Novobiocin (Gambar 1). Namun, sifat Staphylococcus aureus yang tidak biasa ditemukan pada umumnya adalah koagulase negatif pada uji koagulase. Penelitian yang dilakukan oleh Toelle et al. (2014), Lestari et al. (2015), dan Karimela et al. (2017) juga menemukan isolat bakteri Staphylococcus aureus koagulase negatif. $18-20$ Staphylococcus aureus pada umumnya menghasilkan koagulase positif, tetapi dapat ditemukan juga Staphylococcus aureus koagulase negatif. 18,20

Penelitian ini menemukan sebanyak 90,5\% bakteri CoNS dan 9,5\% bakteri Staphylococcus aureus koagulase positif pada telepon genggam. Persentase bakteri CoNS lebih besar daripada bakteri Staphylococcus aureus koagulase positif juga terdapat pada penelitian sebelumnya. Penelitian yang dilakukan Haghbin et al. (2015) dan Attia et al. (2020) menunjukkan bahwa persentase bakteri CoNS yang menjadi kontaminan telepon genggam lebih besar, yaitu $40 \%$ hingga $73 \%$, daripada bakteri Staphylococcus aureus koagulase positif, yaitu $16 \%$ hingga $17 \% .{ }^{26,27}$

Salah satu kemungkinan faktor risiko ditemukannya bakteri CoNS lebih banyak daripada bakteri Staphylococcus aureus koagulase positif di telepon genggam adalah karena bakteri tersebut berasal dari bakteri floral normal di kulit. Bakteri dari genus Staphylococcus yang paling sering ditemukan sebagai komensal flora normal di kulit adalah bakteri CoNS. Selain bakteri CoNS, bakteri dari genus Staphylococcus lainnya yang terdapat di kulit adalah bakteri Staphylococcus aureus koagulase positif. Namun, Staphylococcus aureus koagulase positif hanya ditemukan sesekali dan dalam jumlah kecil. ${ }^{30,31}$ 
Di sisi lain, bakteri CoNS dan Staphylococcus aureus koagulase positif dapat menimbulkan manifestasi klinis pada kondisi dan faktor risiko tertentu, misalnya faktor virulensi tertentu yang dimiliki oleh bakteri, pasien immunocompromised, dan barier kulit yang rusak. ${ }^{31-33}$ Sebanyak $75 \%$ infeksi yang disebabkan oleh bakteri CoNS adalah karena bakteri Staphylococcus epidermidis. ${ }^{30}$ Bakteri Staphylococcus epidermidis banyak ditemukan sebagai patogen penyebab infeksi nosokomial sepsis pada pasien immunocompromised, neonatus, dan pasien dengan peralatan medis invasif. $31,34,35$

Selain bakteri CoNS, bakteri Staphylococus aureus juga dapat menimbulkan manifestasi klinis, seperti keracunan makanan, staphylococcal scalded skin syndrome, dan staphylococcal toxic shock syndrome. ${ }^{30}$ Staphylococcus aureus dapat menimbulkan manifestasi klinis karena beberapa faktor risiko baik dari hospes maupun agens. ${ }^{32,36}$ Salah satu faktor risiko dari agens Staphylococcus aureus adalah faktor virulensi, misalnya protein-A, enzim, dan toksin. ${ }^{36}$ Protein-A berguna untuk menghambat proses imunologi. Berdasarkan penelitian Lestari et al. (2015) bakteri Staphylococcus aureus koagulase positif yang memiliki protein-A mempunyai pertahanan lebih kuat terhadap fagositosis dibandingkan Staphylococcus aureus koagulase negatif yang tidak memiliki protein-A. Dengan kata lain, Staphylococcus aureus koagulase positif lebih patogen daripada Staphylococcus aureus koagulase negatif. ${ }^{19}$ Limitasi penelitian ini hanya mengidentifikasi spesies bakteri yang ditemukan pada telepon genggam dan menjelaskan bakteri tersebut secara umum dapat menimbulkan berbagai penyakit berdasarkan literatur sebelumnya.

\section{Kesimpulan}

Penelitian ini menyimpulkan bahwa bakteri yang dominan menjadi kontaminan telepon genggam adalah bakteri Staphylococcus koagulase negatif.

\section{Saran}

Saran bagi penelitian selanjutnya diharapkan untuk melakukan penelitian dengan menggunakan besar sampel lebih banyak untuk mengetahui seberapa besar korelasi bakteri CoNS dan Staphylococcus aureus koagulase positif pada telepon genggam dengan angka kejadian penyakit infeksi. Saran bagi seluruh peserta PPDS-1, khususnya di Departemen IImu Kesehatan Anak, diharapkan tetap melakukan hand hygiene, desinfeksi telepon genggam, melapisi telepon genggam dengan plastik, dan rutin mengganti lapisan plastik tersebut.

\section{Daftar Pustaka}

1. Crysansia $T$, Lasmini $T$. Identifikasi Bakteri Kontaminan pada Usap Telepon Genggam Layar Sentuh Mahasiswa Akademi Kesehatan John Paul II Pekanbaru. Jurnal Sains dan Teknologi Laboratorium Medik. 2018; 3(1):8-13.

2. Sofyana B. Gambaran Mikroorganisme pada Handphone Petugas Medis di RS USU Tahun 2018. [Skripsi]. Repository Institusi Universitas Sumatera Utara. 2018.

3. Bodena D, Teklemariam Z, Balakrishnan S, Tesfa T. Bacterial Contamination of Mobile Phones of Health Professionals in Eastern Ethiopia: Antimicrobial Susceptibility and Associated Factors. Tropical Medicine and Health. 2019; 47 (15):1-10.

4. Heyba M, Ismaiel M, Alotaibi $A$, Mahmoud M, Baqer H, Safar A, et al. Microbiological Contamination of Mobile Phones of Clinicians in Intensive Care Units and Neonatal Care Units in Public Hospitals in Kuwait. BMC Infectious Diseases. 2015; 15(434):1-9. 
5. Banawas S, Abdel-Hadi A, Alaidarous M, Alshehri B, Bin Dukhyil AA, Alsaweed M, et al. Multidrug-Resistant Bacteria Associated with Cell Phones of Healthcare Professionals in Selected Hospitals in Saudi Arabia. Canadian Journal of Infectious Diseases and Medical Microbiology. 2018; 2018:1-7.

6. WHO. Report on the Burden of Endemic Health Care-Associated Infection Worldwide Clean Care is Safer Care. Geneva: WHO Document Production Services. (Online). 2011. https:// www.who.int/gpsc/country_work/ burden_hcai/en/ [Diakses 1 September 2021].

7. Simon AK, Hollander GA, McMichael A. Evolution of The Immune System in Humans from Infancy to Old Age. Proceedings of the Royal Society $B$ : Biological Sciences. 2015; 282(1821):1-9.

8. Urzedo JE, Levenhagen MMMD, Pedroso RS, Abdallah VOS, Sabino SS, Brito DVD. Nosocomial Infections in A Neonatal Intensive Care Unit during 16 years: 19972012. Revista da Sociedade Brasileira de Medicina Tropical. 2014; 47(3):321-6.

9. Dal-Bó K, Silva RM, Sakae TM. Nosocomial Infections in A Neonatal Intensive Care Unit in South Brazil. Revista Brasileira de Terapia Intensiva. 2012; 24(4):381-5.

10. Dashti AS, Kadivar MR, Tabatabai A, Zand F, Salami S, Ezadpanah S, et al. Prevalence of Healthcare-Associated Infections in Pediatric Wards of Nemazee Teaching Hospital in Shiraz: A Comparison with The Whole Hospital. Archives of Pediatric Infectious Diseases. 2019; 7(1):1-6.

11. Departemen IImu Kesehatan Anak FK UNAIR. Buku Panduan Program Pendidikan Dokter Spseialis Anak. $4^{\text {th }}$ ed. Surabaya: Surabaya Intellectual Club; 2016.
12. Jannah MM, Ricky M, Anggraini DI, Sholeha TU. Identifikasi Bakteri pada Layar Telepon Genggam Petugas Medis di RSUD A. Dadi Tjokrodipo Bandar Lampung. Medula. 2017; 7(5):96-9.

13. Soedarto. Mikrobiologi Kedokteran. Jakarta: Sagung Seto. 2015.

14. Warsa UC. Kokus Positif Gram. Dalam: Buku Ajar Mikrobiologi Kedokteran. Ciputat: Binarupa Aksara Publisher. 2010.

15. Vandepitte J, Verhaegen J, Engbaek K, Rohner P, Piot P, Heuck CC. Prosedur Laboratorium Dasar untuk Bakteriologi Klinik. Setiawan L (Penerjemah). Edisi ke2. Jakarta: EGC. 2010.

16. Koendhori EB, Kusumaningrum D, Mertaniasih NM, Widhyatmoko DB. Bakteriologi Infeksi Kulit dan Jaringan Lunak. Dalam: Alimsardjono L, Wahyunitisari MR, Setiabudi RJ, Juniastuti, Kusumaningrum D, Endraswari PD. (eds.) Buku Ajar Pemeriksaan Mikrobiologi pada Penyakit Infeksi. Edisi ke-2. Jakarta: Sagung Seto. 2019.

17. Tille PM. Bailey \& Scott's Diagnostic Microbiology. 14th ed. St. Louis, Missouri: Elsevier. 2017.

18. Toelle NN, Lenda V. Identifikasi dan Karakteristik Staphylococcus Sp. dan Streptococcus Sp. dari Infeksi Ovarium pada Ayam Petelur Komersial. Jurnal IImu Ternak. 2014; 1(7):32-7.

19. Lestari FB, Salasia SIO. Karakterisasi Staphylococcus aureus Isolat Susu Sapi Perah Berdasar Keberadaan Protein-A pada Media Serum Soft Agar terhadap Aktivitas Fagositosis Secara In Vitro. Jurnal Sain Veteriner. 2015; 33(2):149 55.

20. Karimela EJ, ljong FG, Dien HA. Karakteristik Staphylococcus aureus yang di Isolasi dari Ikan Asap Pinekuhe Hasil Olahan Tradisional Kabupaten Sangihe. Jurnal Pengolahan Hasil Perikanan Indonesia. 2017; 20(1):188-98. 
21. Daoudi A, Slitine NEI, Bennaoui F, Alaoui MM, Soraa N, Maoulainine FMR. Study of Bacterial Contamination of Mobile Phones and Stethoscopes in Neonatal Intensive Care Unit. International Journal of Pediatrics. 2017; 5(11):6139-42.

22. Cantais A, Grattard F, Gagnaire J, Mory O, Plat A, Lleres-Vadeboin $M$, et al. Longitudinal Study of Viral and Bacterial Contamination of Hospital Pediatricians' Mobile Phones. Microorganisms. 2020; 8 (12):1-11.

23. Kementerian Kesehatan RI. Pedoman Pencegahan dan Pengendalian Coronavirus Disease (COVID-19). Edisi Ke-5. Jakarta: Kementerian Kesehatan RI. 2020.

24. CDC. COVID-19 Overview and Infection Prevention and Control Priorities in nonUS Healthcare Settings. (Online). 2021. https://www.cdc.gov/coronavirus/2019ncov/hcp/non-us-settings/overview/ index.html [Diakses 1 September 2021].

25. Koscova J, Hurnikova Z, Pistl J. Degree of Bacterial Contamination of Mobile Phone and Computer Keyboard Surfaces and Efficacy of Disinfection with Chlorhexidine Digluconate and Triclosan to Its Reduction. International Journal Environmental Research and Public Health. 2018; 15(10):2238.

26. Haghbin S, Pourabbas B, Serati Z, Alborzi A. Bacterial Contamination of Mobile Phones and Pens in Pediatric and Neonatal Intensive Care Units. International Journal of Current Microbioliogy and Applied Science. 2015; 4(2):75-81.

27. Attia TAE-R, Amer OT, Asaad AMM, Mohamed MEB. Bacterial Contamination of Healthcare Workers' Mobile Phones in Pediatric and Neonatal Departments of Two Hospitals in Zagazig City. Zagazig University Medical Journal. 2020; 26 (3):384-96.
28. Zaman RMQ, Helmi NRM. Isolation of Bacteria from Mobile Phones Before and After Decontamination: Study Carried Put at King Abdulaziz University, Jeddah, Saudi Arabia. African Journal of Microbiology Research. 2017; 11 (35):1371-8.

29. Sinuhaji SC. Perbedaan Jenis Mikrobiota Normal Kulit pada Pria Dewasa dan Lanjut Usia. [Tesis]. Repository Institusi Universitas Sumatera Utara. 2019.

30. Brooks GF, Carroll KC, Butel JS, Morse SA, Mietzner TA. Jawetz, Melnick, \& Adelberg's Medical Microbiology. 26 2 th $^{\text {ed. }}$ New York: McGraw-Hill. 2013.

31. Nuryastuti T. Staphylococcus epidermidis: How to Turn from Commensal to be A Pathogen Lifestyle. Journal of the Medical Sciences. 2018; 50(1):113-27.

32. Wanke I, Skabytska Y, Kraft B, Peschel A, Biederman T, Schittek B. Staphylococcus aureus Skin Colonization is Promoted by Barrier Disruption and Leads to Local Inflammation. Experimental Dermatology. 2013; 22(2):141-59.

33. Yang JJ, Chang TW, Jiang $Y$, Kao HJ, Chiou BH, Kao MS, et al. Commensal Staphylococcus aureus Provokes Immunity to Protect Against Skin Infection of Methicillin-Resistant Staphylococcus aureus. International Journal of Molecular Science. 2018; 19(5):1290.

34. Dong Y, Speer CP. The Role of Staphylococcus epidermidis in Neonatal Sepsis: Guarding Angel or Pathogenic Devil. International Journal of Medical Microbiology. 2014; 304(5-6):513-20.

35. Marchant EA, Boyce GK, Sadarangani M, Lavoie PM. Neonatal Sepsis due to Coagulase-Negative Staphylococci. Journal of Immunology Research. 2013;2013:1-10.

36. Husna CA. Peranan Protein Adhesi Matriks Ekstraselular dalam Patogenitas Bakteri Staphylococcus Aureus. Jurnal Averrous. 2018; 4(2):1-12. 